\title{
United Nations Peace-Keeping
}

\section{Ambassador Edward J. Perkins ${ }^{\dagger}$}

For many years, what we now call classic "peace-keeping" stood out as one of the great and imaginative contributions of the United Nations. The scope and process of peace-keeping have evolved over time, as the institution of peace-keeping has developed and as international conditions have changed. The award of the 1988 Nobel Peace Prize to the U.N. Peace-Keeping Forces reflects the magnitude and increasing success of the United Nations ongoing contributions.

Faced with a world which could not use the enforcement mechanisms of the U.N. Charter because of disagreement among the major powers, the United Nations invented peace-keeping. Among the many conflicts encountered were those which took place in vacuums or partial vacuums created by the end of the era of European colonialism. In some cases, the conflicts were exacerbated by East-West rivalry to fill the vacuum. Thus, although these confrontations grew from local conflicts, they were often affected and aggravated by the major powers.

Peace-keeping during the first four decades of the United Nations had two primary components: verification and interposition. Peace-keeping by verification used U.N. observers to confirm that parties to a cease-fire or armistice agreement were complying with its terms. Peace-keeping by interposition stationed U.N. Blue Helmets between opposing forces to obstruct armed conflict. The function of both types of peace-keeping was to prolong and, if possible, institutionalize moments of mutual temporary sanity between opposing forces in order to give the parties an opportunity to solve or sufficiently ameliorate their underlying problems. The U.N. peace-keepers thus far have successfully prolonged cease-fires and truces, although they have been less successful in their attempts actually to bring about resolutions of the underlying conflicts.

The clearest and earliest example of a successful peace-keeping effort is the Namibian mission, a complex operation in which multilateral, bilateral, and trilateral peacemaking efforts combined to create conditions in which a complex military and civilian operation (UNTAG) oversaw the transition of Namibia from an illegally occupied former League of Nations mandate to an independent State. Democratic elections and a Constitution reflecting respect for individual liberty played a prominent part in this process. The U.N. contribution was indispensable.

$\dagger$ Career Foreign Service Officer with the rank of Career Minister. Until recently, Ambassador Perkins was U.S. Permanent Representative to the United Nations. He has also been Director General of The Foreign Service and U.S. Ambassador to the Republic of South Africa. 
Due to the success of peace-keeping by interposition and the winding down of the East-West rivalry, increasingly complex uses have been made of peacekeeping forces in the last few years. Peace-keepers are now being given a role as an integral part of the peacemaking process, rather than the more limited role of buying time. In other words, the institutionalization of peacemaking has become an unstated aim of the United Nations. For example, today even more intricate negotiations and plans are in place for Cambodia. A U.N. operation is seeking to move that troubled land from chaos and civil war to peace. Unfortunately, however, the process has encountered several problems thus far, all of which flow from the failure of the Khmer Rouge to cooperate with the operation in accordance with the Paris Accord of 1991. The Secretary-General, his Special Representative, well-placed regional powers, and the co-chairmen of the Paris Conference are all seeking to find ways to overcome these problems.

El Salvador and Angola are the sites of other complex U.N. operations supervising a process of transition from civil war to peace. Iraq, Yugoslavia, and Somalia represent still other imaginative uses of U.N. peace-keeping in the broadest possible sense of the term to ameliorate tragic situations. Iraq, for example, involves both UNIKOM, a relatively traditional peace-keeping operation in the demilitarized zone between Iraq and Kuwait, and the innovative institution of U.N. guards whose primary function is to secure U.N. property and personnel but whose presence casts a far longer shadow. Indeed, some aspects of the U.N. mission in Somalia were inspired in part by the use of guards in Iraq. Because these efforts around the globe are in many ways novel, it is not surprising that they efforts have experienced difficulties.

U.N. Peace-keepers confront problems that are not easy to resolve, whether they are the refusal to honor a commitment to accept election results in Angola, or the insistence of authorities in Croatia that U.N. peace-keepers apply Croatian law to deport refugees. Resolving these problems will take patience, determination, good luck, and will. Despite the encouraging new uses of U.N. peace-keeping, many difficult issues loom ahead. These issues include the question of how the United Nations should respond when internal chaos prevents anyone from speaking on behalf of a country (like Somalia) and the question of what degree of humanitarian suffering and deprivation provides a sufficient basis for authorizing the United Nations or its Member States to take action.

The United Nations must be strengthened if it is to have a chance of solving any or most of these problems. Key international actors have recognized the necessity of enhancing the ability of the United Nations to engage in preventative diplomacy and peacemaking. For example, the Security Council statement of January 31, 1992, President Bush's statement of September 21, 1992, and the Secretary-General's Agenda for Peace have all 
recognized this fact. These statements ${ }^{1}$ are a promising beginning. The Secretary-General, for example, has suggested increasing fact-finding by the United Nations, increasing information flows to the United Nations, and enhancing the role of regional agencies. There is certainly room for enhancing the role of regional organizations and for improving contact between the United Nations and those organizations, although the present ability of some regional organizations is obviously greater than that of others. The Security Council and the General Assembly's Special Committee on the Charter of the United Nations and on Strengthening the Role of the Organization is pursuing these matters further.

Clearly, the existing problems with which the United Nations is wrestling are difficult, indeed daunting. We must not expect the United Nations to solve, or even address, every problem that comes its way. Nevertheless, these statements and suggestions, together with the responsibility to date of Member States, mark a good beginning towards equipping the United Nations to deal more effectively with the complex issues it is now being asked to resolve.

1. Agenda for Peace: Preventative Diplomacy, Peacemaking and Peace-Keeping, Report of the Secretary-General, U.N. SCOR, 47th Sess., U.N. Doc. S/24111 (1992); U.N. SCOR, 47th Sess., 3046th mtg., at 3, U.N. Doc. S/23500 (1992). 
